\title{
ポーラスコンクリートの圧縮強度推定式の構築に関する研究 STUDY ON AN EQUATION FOR PREDICTING COMPRESSIVE STRENGTH OF POROUS CONCRETE
}

\author{
大谷俊浩*, 村上 聖**, 佐藤嘉昭***, 三井宜之****, 平居孝之***** \\ Toshihiro OTANI, Kiyoshi MURAKAMI, Yoshiaki SATO, \\ Yoshiyuki MITSUI and Takayuki HIRAI
}

\begin{abstract}
The object of this paper is to propose an equation for predicting compressive strength of porous concrete. The factors influencing mainly the compressive strength of porous concrete were picked out. The proposed equation was constituted with the following three factors; void ratio, water cement ratio and oven-dry density of coarse aggregate. It is found that the 28 -day compressive strength of porous concrete can be estimated by using the proposed equation. However, the influence of the type of cement was not clarified because its limited data.
\end{abstract}

Keywords: Porous Concrete, Equation for Predicting Strength, Compressive Strength, Coarse Aggregate Strength, Binding Strength ポーラスコンクリート, 強度推定式, 圧縮強度, 骨材強度, 結合強さ

1.はじめに

ポーラスコンクリートは内部に連続した空隙を多量に有するコン クリートである。その形状特性から，通気や透水が可能であり，近年 地球環境問題がクローズアップされるなか, 環境負荷低減や環境共生 が可能なエココンクリート ${ }^{1)}$ として注目され，多くの研究成果が報 告されている ${ }^{2)}$ 。しかしながら，ポーラスコンクリートの圧縮強度特 性一つをとりあげてみても,十分な検討がなされているとは言えない のが現状である。今後, ポーラスコンクリートの利用を拡大していく ためには, 要求された性能を保証できるような調合設計法の確立が必

要であり，そのためには強度理論体系を確立する必要がある。

ポーラスコンクリートの圧縮強度特性に影響を及ぼす影響要因と 関連因子は表 1 のように整理される。筆者らはこれまでの研究により， 空隙率については, 多くの研究報告で報告されているように, 空隙率 が高くなるほど圧縮強度は低下し, その関係はある指数関数で近似で きることを明らかとしている ${ }^{3)}$ 。また，振動締固めおよび骨材粒径の 影響については，硬質砂岩砕石を用いた実験より，振動締固めは結合 材の分布状態に大きく影響し，それが圧縮強度に影響を及ぼすこと，
表 1 圧縮強度の影響要因と関連因子

\begin{tabular}{c|c}
\hline 影響要因 & 関連因子 \\
\hline \hline 空隙率 & (調合), 壁効果 \\
\hline 結合強さ & 水セメント比, セメント種類, 養生方法, 材齢 \\
\hline 骨材強度 & 骨材種類 \\
\hline 骨材粒径 & 骨材種類 \\
\hline 締固めの程度 & 締固めの方法・時間 \\
\hline
\end{tabular}

また, 骨材粒径の違いはポーラスコンクリート作製時の壁効果の影響 により骨材の㥶積率の変化を招き, 圧縮強度の変化はその影響による ものであり，骨材粒径が直接的に圧縮強度に影響を及ぼすものではな いことを明らかとしている ${ }^{3)}$ ささらに，結合強さに関しては，理想球 形骨材を使用した実験により圧縮強度はセメント水比の增加ととも に直線的に増加することなどを明らかとした ${ }^{4)}$ 。

一方, ポーラスコンクリートは, あまり高い強度を必要せず, 近年 の天然骨材採取規制に伴い再生骨材などの低品質骨材の用途として 注目されている。ポーラスコンクリートの強度特性に及ぼす影響は, 良質な天然骨材を使用すれば問題ないが, 骨材はポーラスコンクリー

\footnotetext{
* 大分大学工学部福祉環境工学科 助手 $\cdot$ 工修

** 熊本大学大学院自然科学研究科 助教授・ 工博

*** 大分大学工学部福祉環境工学科 教授 $\cdot$ 工博

**** 熊本大学工学部環境システム工学科 教授・工博

***** 日本文理大学工学部建築デザイン学科 教授・工博
}

Research Assoc., Dept. of Architectural Eng., Faculty of Eng., Oita Univ., M. Eng. Assoc. Prof., Graduate School of Science and Technology, Environmental Science, Kumamoto Univ., Dr. Eng.

Prof., Dept. of Architectural Eng., Faculty of Eng., Oita Univ., Dr. Eng.

Prof., Dept. of Architecture and Civil Eng., Faculty of Eng., Kumamoto Univ., Dr. Eng.

Prof., Dept. of Architectural Designs, Faculty of Eng., Nippon Bunri Univ., Dr. Eng. 
卜容積の $55 \%$ 程度（かさ容積ではほぼ 100\%）を占め，そのような低 品質の骨材を使用した場合, 強度特性に影響を及ぼすことは容易に想 像できることである。しかしながら，骨材強度の影響について険討を 行った報告は少なく ${ }^{5)}$ 充分な評価に至っていないのが現状である。

そこで, 本研究では骨材強度がポーラスコンクリートの圧縮強度特 性に及ぼす影響を検討し，圧縮強度の影響要因を整理することで調合 設計法の確立に必要な汎用的な強度推定式の構築を行うこととした。

\section{2. 実験方法}

\section{1 実験概要}

ポーラスコンクリートのマトリックスは, 粗骨材を最密充填するよ うに形成されているため, 作用する荷重は, 骨材の接点を介して伝達 される。ポーラスコンクリートの圧縮破壊形態には村尾ら ${ }^{6)}$ が指摘 しているように，結合材の破壊，結合材と骨材界面の破壃，および骨 材破壊の 3 種類が存在し，骨材破壊が支配的破壊形態である場合，骨 材強度の影響を受けるが, その他が支配的要因となる場合, 骨材強度 の影響は小さくなることが予想される。したがって, 骨材強度がポー ラスコンクリートの圧縮強度に及ぼす影響を調べるうえで破壊形態 の影響を考慮する必要がある。支配的破壊形態を決定する条件として， 結合強さと骨材強度が大きく関わっている。上述の上うに，力は骨材 の接点を介して伝達されるため, 力の作用線と骨材配列の方向が同一 でない限り，骨材接点はせん断力を受ける。骨材接点部分は結合材に より拘束されていることから，接点部分の結合材のせん断破壊と骨材 の圧縮割裂破壊の大小により，その接点部分の破壊形態が決定される。 また, 接点部分の結合の強さは, 結合材自体の強度と量により変化す る。そこで,骨材強度として骨材種類を変化させ, 結合強さとしては, 結合材自体の強度による影響は既報の研究 ${ }^{4)}$ で明らかにしているこ とから，今回は，結合材量の影響を明確にすることを含め，結合材量 を変化させた供試体を作製し, 骨材強度がポーラスコンクリートの圧 縮強度に及ぼす影響について検討した。

\section{2 使用材料および調合}

表 2 に使用材料を示す。セメントは高炬セメント B 種を使用した。 粗骨材は, 硬質砂岩砕石骨材, 再生骨材, 高炉徐冷スラグ骨材および 人工軽量骨材の強度の異なる 4 種類を使用した。今回, 実験に使用し た再生骨材泣，モルタル分が多く残っているため 6\%を超える高い吸 水率を示しているが，TR A 0006 に規定される再生粗骨材の品質（吸 水率 7\%以下）を満足するものである。また，高炉徐冷スラグ骨材は， 多孔質であるため吸水率が比較的高くなっており，JIS A 5011 によれ ばL区分に相当する。

表 3 に調合を示す。結合材は細骨材を使用せず，セメントペースト とした。セメントペーストの水セメント比を $25 \%$ で一定とし，目標空 隙率を表に示すように段階的に変化させた調合とした。また，セメン トペーストのフロー值は, 高性能 $\mathrm{AE}$ 減水剤の添加量を調整すること で $200 \pm 10 \mathrm{~mm}$ に調整した。なお，人工軽量骨材を使用したものにつ いては，供試体用型枠を使用して求めた骨材の実積率を使用して，調 合を決定した。

\section{3 供試体作製}

人工軽量骨材以外の骨材を使用したものの練混ぜは, 容量 100 リッ

\section{表 2 使用材料}

\begin{tabular}{|c|c|c|}
\hline $\begin{array}{c}\text { セメント } \\
\text { 粗骨材 }\end{array}$ & \multicolumn{2}{|c|}{ 高炉セメント B 種 : 密度 $3.04 \mathrm{~g} / \mathrm{cm}^{3}$} \\
\hline \multirow{12}{*}{ 粗骨材 } & 硬質砂岩砕石 5 号： & \multirow{6}{*}{$\begin{array}{l}\text { 再生骨材: } \\
\text { 表乾密度 } \quad 2.43 \mathrm{~g} / \mathrm{cm}^{3} \\
\text { 絶乾密度 } \quad 2.24 \mathrm{~g} / \mathrm{cm}^{3} \\
\text { 吸水率 } \quad 6.24 \% \\
\text { 粒径 } \quad 5 \sim 20 \mathrm{~mm} \\
\text { 実積率 } \quad 56.8 \%\end{array}$} \\
\hline & 表乾密度 $2.64 \mathrm{~g} / \mathrm{cm}^{3}$ & \\
\hline & 絶乾密度 $2.62 \mathrm{~g} / \mathrm{cm}^{3}$ & \\
\hline & \multirow{3}{*}{$\begin{array}{l}\text { 吸水率 } \quad 1.02 \% \\
\text { 粒径 } \quad 13 \sim 20 \mathrm{~mm} \\
\text { 実積率 } \quad 55.9 \%\end{array}$} & \\
\hline & & \\
\hline & & \\
\hline & \multirow{6}{*}{$\begin{array}{l}\text { 高炉徐冷スラグ骨材: } \\
\text { 表乾密度 } 2.47 \mathrm{~g} / \mathrm{cm}^{3} \\
\text { 絶乾密度 } 2.36 \mathrm{~g} / \mathrm{cm}^{3} \\
\text { 吸水率 } \quad 4.47 \% \\
\text { 粒径 } \quad 5 \sim 25 \mathrm{~mm} \\
\text { 実積率 } \quad 51.6 \%\end{array}$} & \multirow{6}{*}{$\begin{array}{l}\text { 人工軽量骨材: } \\
\text { 絶乾密度 } 0.85 \mathrm{~g} / \mathrm{cm}^{3} \\
\text { 吸水率 } 4.00 \% \\
\text { 粒径 } 10 \mathrm{~mm} \text { 以上 } \\
\text { 実積率 } \quad 54.7 \%\end{array}$} \\
\hline & & \\
\hline & & \\
\hline & & \\
\hline & & \\
\hline & & \\
\hline 混和剤 & \multicolumn{2}{|c|}{ ポリカルボン酸系高性能 $\mathrm{AE}$ 減水㓣 } \\
\hline
\end{tabular}

表 3 調合

\begin{tabular}{c|c|c}
\hline 骨材種類 & $\begin{array}{c}\text { 水セメント比 } \\
(\%)\end{array}$ & $\begin{array}{c}\text { 目標空隙率 } \\
(\%)\end{array}$ \\
\cline { 1 - 1 } 硬質砂岩砕石 5 号 & \multirow{3}{*}{25} & $5,10,15,20,25$ \\
\cline { 1 - 1 } 再生 & \multirow{2}{*}{\begin{tabular}{c} 
高炉徐冷スラグ \\
\cline { 1 - 1 } 人工軽量
\end{tabular}} & $0,10,15,20,25$ \\
& & $0,10,15,20,25$ \\
& & $(5,10,11,20,22,30) *$ \\
\hline
\end{tabular}

*：供試体用型枠 $(\phi 10 \times 20 \mathrm{~cm})$ にて算出した骨材実積率を使用

トルの強制 2 軸ミキサを使用し，セメントと骨材の空練りを行った後， 水および混和剤を投入して筧找し，コンクリートを作製した。人工軽 量骨材を使用したものは，強制 2 軸ミキサによる混練は骨材の破壊を 生じやすいため, 混練には容量30リットルのオムニミキサを使用し， セメントペーストを先練りした後，骨材を投入して筧拌し，コンクリ 一トを作製した。練り上げたコンクリートは $\phi 10 \times 20 \mathrm{~cm}$ に投入し， 締固めは振動によって結合材の分布状態に偏りが生じた場合, 強度特 性に影響を及ぼすため ${ }^{3)}$ ，その影響を排除することを目的に，突き棒 および木づちでセメントペーストに垂れが生じないように注意しな がら充分に突き固めた。

作製した供試体は，材齢 1 日で脱型して $20^{\circ} \mathrm{C}$ 水中養生を行い，コ ンクリートが充分硬化した後, 空隙率の測定を行った。空隙率の測定 は, 日本コンクリート工学協会ポーラスコンクリートの物性試験方法

(案) ${ }^{1)}$ に準拠して容積法で行った。空隙率の測定後は再び $20^{\circ} \mathrm{C}$ 水中 養生を継続し，材齿 28 日で圧縮強度試験に供した。

\section{3. 実験結果および考察}

表 4 に実験結果デー夕を平均値で示す。また，図 1 に圧縮強度と空 隙率の関係を示す。図より，使用する骨材の種類により同一空隙率に おける圧縮強度に差が生じており，高強度になるほど差が大きくなる 傾向にある。全体的にみて人工軽量骨材, 再生骨材, 高炉徐冷スラグ 骨材，硬質砂岩砕石の順に圧縮強度が低くなっていることがわかる。 このように強度差を生じた原因として, 空隙率が小さい, すなわち結 合材量が多いほど，骨材接点の結合強さが高くなるために，骨材強度 が相対的に小さくなり，骨材の割裂破壊が増加することで，骨材強度 の影響が明確化してきたものと考えられる。したがって，上記の順に 骨材強度が小さいものと推察される。 


\section{4. 強度推定式の構築}

\section{1 圧縮強度推定式の基本構成}

強度推定式は，簡便で, かつ材料データにより推定できるものが望 ましい。そこで, 影響係数を空隙率, 骨材強度抢よび結合強さの 3 つとし，図 2 に示す硬質砂岩砕石を使用した既報の実験データの圧縮 強度と空隙率の関係の回帰結果 ${ }^{3)}$ を参考に強度推定式の構成を次式 のように仮定した。

$F c=\alpha \cdot \beta \cdot e^{-0.06 V a}$

ここに, $F c:$ 圧縮強度 $\left(\mathrm{N} / \mathrm{mm}^{2}\right)$

$\alpha, \beta:$ 骨材強度, 結合強さの影響係数 $V a:$ 空隙率 $(\%)$

\section{2 骨材強度指標值}

ポーラスコンクリートに使用する骨材の強度の指標値として考え られるものに密度, 吸水率, 破砕值, 修正破砕率が挙げられる。一般 に, 密度が大きいほど, 吸水率が小さいほど骨材強度が強くなる傾向 にあることは周知の事実である。破砕值は，BS 812 破砕試験により 求めた値である。破砕試験は鋼製の円筒容器に最密充填となるように 充填した試料に所定の荷重を載荷し, $2.5 \mathrm{~mm}$ ふるいを通過するように 破砕された試料の割合を求めるものである。したがって，破砕試験は ポーラスコンクリートの骨材配列に近い状態で行われており, 得られ る值は骨材強度の指標値として利用できると考えられる。また, 石井 が提案している修正破砕率 》) は，破砕試験と同様の試験において破 砕前後の骨材の粒度曲線の差を求めたものであり, 同様に指標值とし て利用できると考えられる。

本実験に使用した骨材の各強度指標値を表 5 に示す。

\section{3 骨材強度の影響係数}

式（1）の骨材強度の影響係数 $\alpha$ を決定するために，表 4 に示すデ 一タの骨材種類ごとに式（1）の結合強さの影響係数 $\beta$ を 1 とした場 合の回帰分析を行うことで各骨材の影響係数を算出し, 表 5 に示す骨 材の各強度指標値との相関性について検討した。算出した影響倸数を 表 6 に示す。表中には既報 ${ }^{3)}$ で使用した他産地の硬質砂岩砕石の影 響係数についても示している。また，図 3 に骨材強度の影響係数 $\alpha$ と 各指標值の関係を示す。図より，骨材の絶乾密度が最も高い相関性を 示していることがわかる。表乾密度も高い相関性を示しており，かつ 一般的に利用されているが, 絶乾密度は吸水率の影響を受けず, 密度 が小さいわりに吸水率が小さな人工軽量骨材のような骨材を含めて 取り扱うことを考えれば，表乾密度より適していると考えられる。そ のため, 絶乾密度を骨材強度の指標値として採用することとした。骨 材強度の影響係数 $\alpha$ は次式で与えられる。

$$
\alpha=12.6 e^{0.61 D d}
$$

ここに, $D d:$ 骨材の絶乾密度 $\left(\mathrm{g} / \mathrm{cm}^{3}\right)$
表 4 実験結果平均データ

\begin{tabular}{|c|c|c|c|}
\hline 骨材種類 & $\begin{array}{c}\text { 目標空隙率 } \\
(\%) \\
\end{array}$ & $\begin{array}{c}\text { 空隙率 } \\
(\%) \\
\end{array}$ & $\begin{array}{c}\text { 圧縮強度 } \\
\left(\mathrm{N} / \mathrm{mm}^{2}\right)\end{array}$ \\
\hline \multirow{5}{*}{ 硬質砂岩砕石 } & 5 & 17.5 & 26.9 \\
\hline & 10 & 21.1 & 20.8 \\
\hline & 15 & 27.0 & 14.2 \\
\hline & 20 & 24.2 & 15.7 \\
\hline & 25 & 30.6 & 10.2 \\
\hline \multirow{5}{*}{ 再生 } & 0 & 6.8 & 32.7 \\
\hline & 10 & 15.7 & 18.0 \\
\hline & 15 & 19.8 & 13.4 \\
\hline & 20 & 23.5 & 13.4 \\
\hline & 25 & 28.9 & 8.1 \\
\hline \multirow{5}{*}{$\begin{array}{c}\text { 高炉徐冷 } \\
\text { スラグ }\end{array}$} & 0 & 14.7 & 24.8 \\
\hline & 10 & 20.4 & 15.3 \\
\hline & 15 & 23.2 & 14.4 \\
\hline & 20 & 29.9 & 9.5 \\
\hline & 25 & 30.2 & 8.7 \\
\hline \multirow{6}{*}{ 人工軽量 } & 5 & 2.0 & 17.1 \\
\hline & 10 & 8.5 & 11.6 \\
\hline & 11 & 11.3 & 11.7 \\
\hline & 20 & 21.7 & 9.8 \\
\hline & 22 & 19.0 & 5.7 \\
\hline & 30 & 29.4 & 3.3 \\
\hline
\end{tabular}

注）供試体数; 人工軽量以外は各 6 体，人工軽量は各 3 体

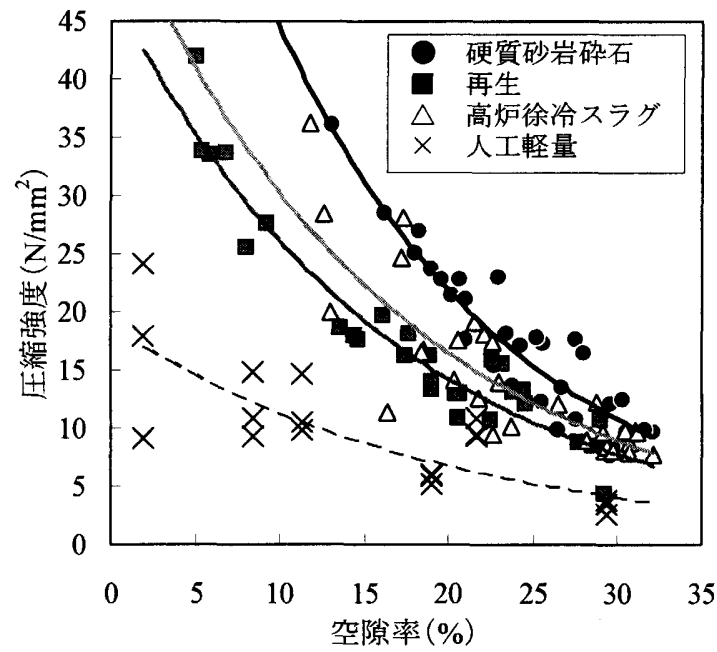

図 1 圧縮強度と空腺率の関係

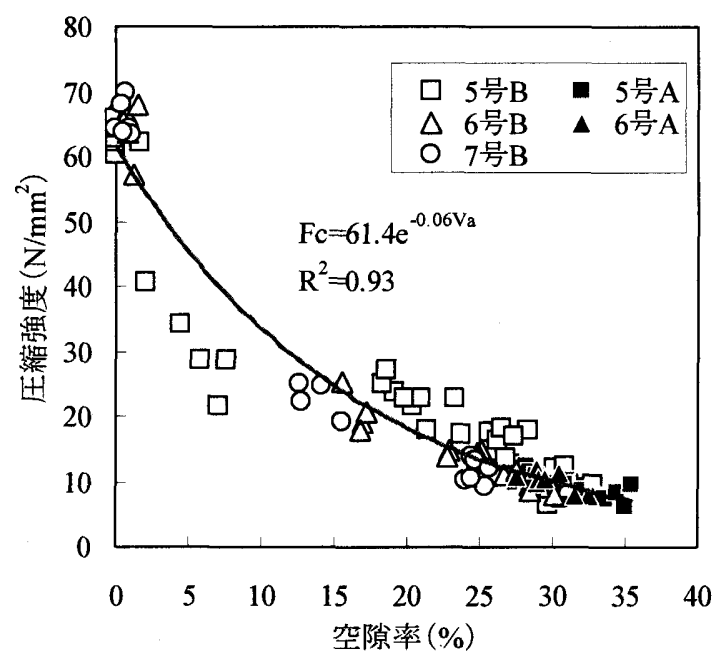

図 2 硬質砂岩砕石を用いた圧縮強度と空隙率の関係 ${ }^{3)}$ 
表 5 骨材の各強度指標值

\begin{tabular}{c|c|c|c|c}
\hline & $\begin{array}{c}\text { 硬質砂岩 } \\
\text { 碎石 5 号 }\end{array}$ & 再生 & $\begin{array}{c}\text { 高炉徐冷 } \\
\text { スラグ }\end{array}$ & 人工軽量 \\
\hline $\begin{array}{c}\text { 表乾密度 } \\
\left(\mathrm{g} / \mathrm{cm}^{3}\right)\end{array}$ & 2.64 & 2.43 & 2.47 & 0.88 \\
\hline $\begin{array}{c}\text { 絶乾密度 } \\
\left(\mathrm{g} / \mathrm{cm}^{3}\right)\end{array}$ & 2.62 & 2.24 & 2.36 & 0.85 \\
\hline $\begin{array}{c}\text { 吸水率 } \\
(\%)\end{array}$ & 1.02 & 6.24 & 4.47 & 4.00 \\
\hline $\begin{array}{c}400 \mathrm{kN} \\
\text { 破砕値 }\end{array}$ & 14 & 24 & 33 & 40 \\
\hline $\begin{array}{c}400 \mathrm{kN} \\
\text { 修正破砕率 }\end{array}$ & 40 & 25 & 46 & 32 \\
\hline
\end{tabular}

\section{4 結合強さの影響係数}

結合強さに影響を及ぼす因子としては表 1 に示すように, 水セメン ト比, セメント種類, 養生方法および材齢が挙げられる。今回の強度 推定式は標準養生材齢 28 日を想定しており，養生方法および材齢に よる影響は考慮しないものとする。水セメント比の影響については, 既報 ${ }^{4)}$ の理想球体骨材を使用したポーラスコンクリートの圧縮強度 試験結果より図 4 に示すように, 圧縮強度とセメント水比の関係は線 形関係で表されることが明らかとなった。この実験では, アルミナボ ールとガラスビーズの 2 種類の理想球形骨材を使用したが, 圧縮強度 試験の結果，両骨材とも骨材の割裂破壊は認められなかったことから， 骨材強度の影響が含まれない水セメント比による結合自体の強度の 影響を正確に表すものと考えられる。ただし, 結合材と骨材の付着破 壇が生じる場合に関しては, 骨材の表面性状が密接に関与しているが, 前節の骨材種類を替えた実験において，その影響も含め，骨材の絶乾 密度で評価できたことから,ここでは付着破壊については考虑しなく てもよいものと考えられる。水セメント比が $25 \%$ の圧縮強度に対寸 る強度比とした場合の水セメント比による結合材の影響係数 $\beta$ は次 式で与えられる。

$$
\begin{gathered}
\beta=k(0.48(C / W)-0.87) \\
\text { ここに, } k: \text { セメント種類による影響係数 } \\
C / W: \text { セメント水比 }
\end{gathered}
$$

式（1），(2)，（3）よりポーラスコンクリートの圧縮強度推定式は次 式となる。

$$
F c=12.6 k(0.48(C / W)-0.87) e^{0.61 D d-0.06 V a}
$$

セメント種類による影響係数について検討するために, ポーラスコ ンクリートの圧縮強度について検討された文献のうち骨材の絶乾密 度が示されたもの（表乾密度および吸水率が示されたものは両値から 算出）についてデータを収集し，強度推定值と実測データの比較を行 った。収集した文献数は 12 件 ${ }^{5), 8 \sim 18)}$, データ数は 159 個であり，本 実験および既報 ${ }^{3)}$ の実験データ 178 個と合わせ計 337 個について検
表 6 各骨材の影響係数 $\alpha$

\begin{tabular}{c|c|c|c|c|c|c|c}
\hline $\begin{array}{c}\text { 砕石 } \\
5 \text { 号 }\end{array}$ & 再生 & $\begin{array}{c}\text { 高炉 } \\
\text { スラグ }\end{array}$ & $\begin{array}{c}\text { 人工 } \\
\text { 軽量 }\end{array}$ & $\begin{array}{c}\text { 砕石 } \\
5 \text { 号 } \mathrm{A}^{*}\end{array}$ & $\begin{array}{c}\text { 砕石 } \\
6 \text { 号 } \mathrm{B}^{*}\end{array}$ & $\begin{array}{c}\text { 砕石 } \\
6 \text { 号 } \mathrm{A}^{*}\end{array}$ & $\begin{array}{c}\text { 砕石 } \\
7 \text { 号 } \mathrm{B}^{*}\end{array}$ \\
\hline 69.6 & 47.2 & 54.5 & 21.2 & 57.3 & 59.3 & 59.6 & 56.0 \\
\hline
\end{tabular}

*既報の使用骨材データ ${ }^{3)}$
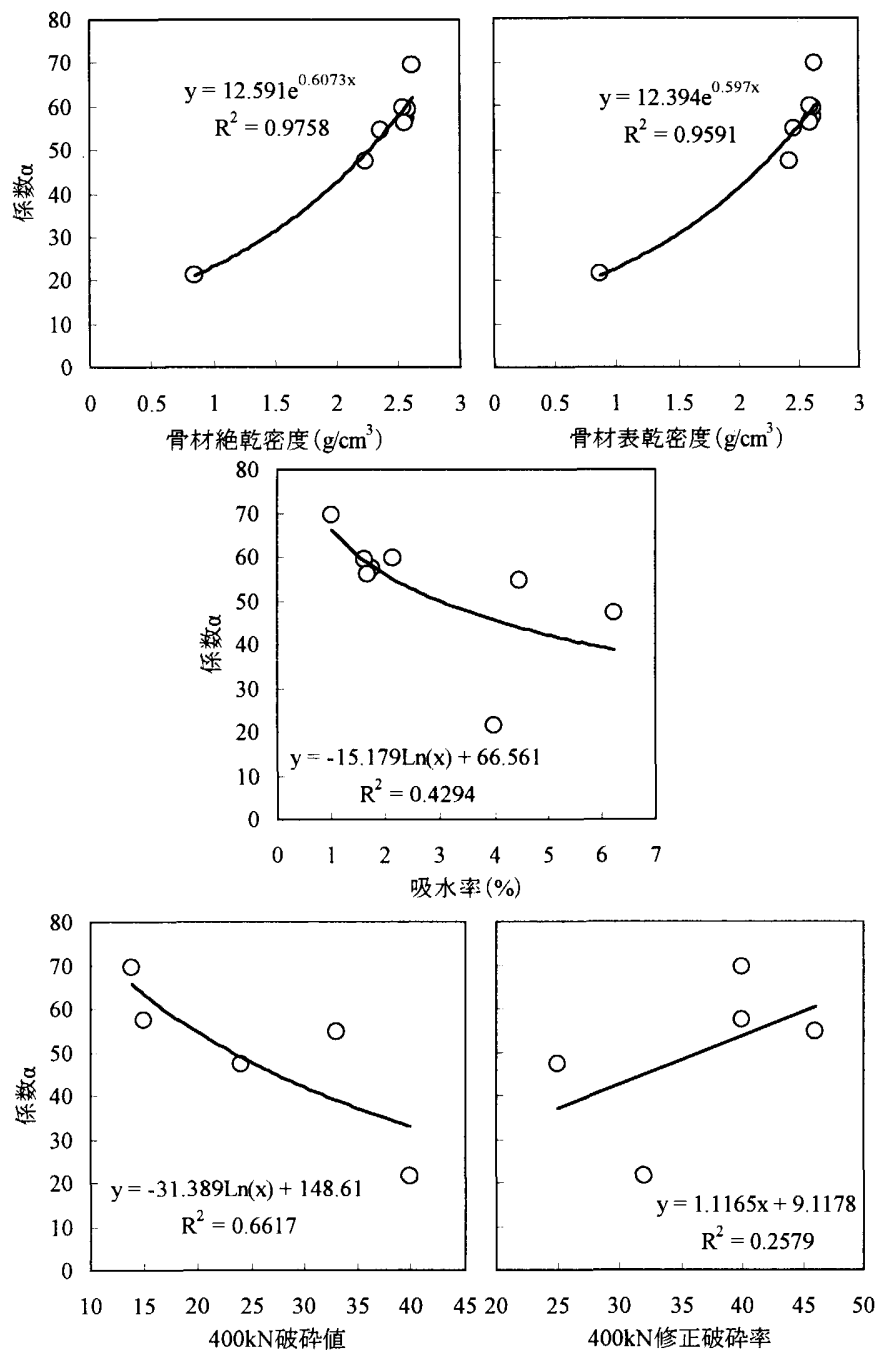

図 3 骨材強度の影響係数 $\alpha$ と各指標值の関係

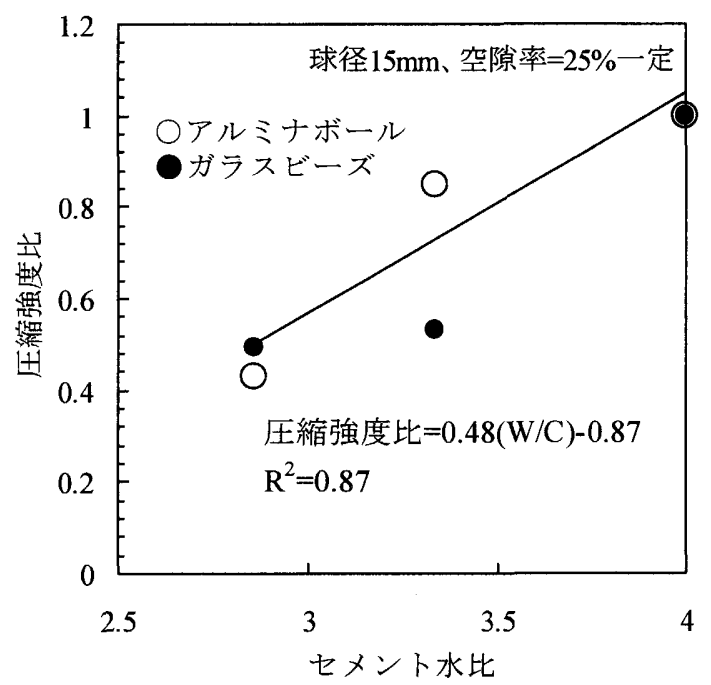

図 4 圧縮強度比とセメント水比の関係 ${ }^{4)}$ 
討した。収集したデータには混和材として高炬スラグ微粉末やシリカ フュームが混入されたデータが存在した。文献 ${ }^{12)}$, 14)、15) ではシリカ フュームまたはシリカ系微粉末が 10〜15\%程度混入され，文献 ${ }^{11)}$ で は普通ポルトランドセメント, 高炬スラグ微粉末およびシリカフュー 厶が質量比で $45: 45: 10$ の比率で混合されている。これらのデータ を用いて推定した結果, シリカフュームを混入した場合は水粉体比よ り水セメント比, 高炉スラグ微粉末およびシリカフュームを混入した 場合は, シリカフュームを除いたセメントと高炉スラグ微粉末による 水粉体比で推定した方が良い結果を示すことがわかった。これは，ポ ーラスコンクリート用混和材として, 高炉スラグはその潜在水硬性に よりコンクリートの強度発現に寄与するが, シリカフューム混入によ る結合材の緻密化は, 明確な強度増加効果を示さないことを示唆して いる。したがって, シリカフュームを混入したものは水セメント比を 使用し, 文献 ${ }^{11)}$ のデータについては, セメントと高炬スラグ微粉末 を合わせて高炉セメント B 種として取り扱い, 同様に水セメント比 で推定した。

図 5 に推定式で推定した圧縮強度と実測した圧縮強度の関係を示 す。図より, 普通ポルトランドセメント, 早強ポルトランドセメント および高炉セメント B 種を使用したものについては推定式による推 定值と実測值と良く対応しているが, 高炉セメント C 種を使用した ものは全体的に推定值が高くなっていることがわかる。表 7 は各セメ ントの推定值と実測值の差である残差の平均を示したものであるが, 高炉セメント C 種が $3 \mathrm{~N} / \mathrm{mm}^{2}$ 以上の差を生じており, 現時点ではデー 夕数が少ないため明確な数值を決定するに至らないが, 高炉セメント C 種についてはある補正係数を乗じる必要があるように思われる。こ のように, 高炬セメントC 種を用いたポーラスコンクリートの圧縮 強度推定值を高く算出した原因は, JIS R 5211 の高炉セメントの品質 において, A, B 種に比べ C 種の材㱓 28 日圧縮強さが $2.5 \mathrm{~N} / \mathrm{mm}^{2}$ 小さ く規定されていること, 高炉スラグを混入したコンクリートに関する 既往の研究 ${ }^{19)}$ で, 高炬スラグのセメント置換率が $50 \%$ より多くなる と材齢 28 日圧縮強度が低下することを示していることからわかるよ うに, 高炉スラグ置換率が 60〜 70\%と高い高炬セメント C 種の材齢 28 日圧縮強度が他のセメントを用いた場合と比較して小さいためで あると考えられる。その他のセメントについては, セメント種類の違 いによる影響は誤差としてみなせる範囲であり, 特に補正係数を乗じ る必要はないと思われる。

\section{5 圧縮強度推定式の適用性の検討}

本推定式の適用性を検討するため, 上記収集データに対してセメン 卜種類による影響係数 $k$ を 1 として推定した圧縮強度と実測值を比較 検討した。図 6 に骨材種類ごとに圧縮強度推定值と実測値の関係を示 す。図より，骨材種類の違いによる推定のずれは確認できず，人工軽 量骨材から天然骨材まで幅広い範囲で適用可能であると考えられる。 また, 四中には全実測値を各推定值で除した值の平均值と, その平均 值の変動係数を示すが, 平均值が 0.99 , 変動係数が $5.47 \%$ と十分な精 度を有していることがわかる。

図 7 は推定値から実測值の差である残差を求めたものであるが, 全 体的な傾向として高強度ほど残差がマイナス側に大きくなり, 本推定 式は圧縮強度を低く見積もる傾向にあることがわかる。

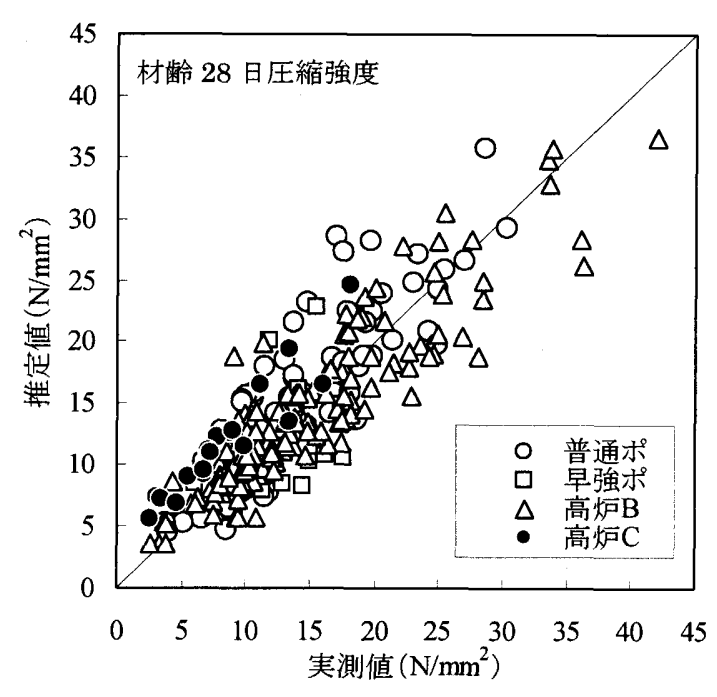

図 5 セメント種類による影響

表 7 残差の平均値 (単位: $\mathrm{N} / \mathrm{mm}^{2}$ )

\begin{tabular}{c|c|c|c}
\hline 普通ポルトランド & 早強ポルトランド & 高炉 B 種 & 高炉 C 種 \\
\hline 1.52 & -0.75 & -0.64 & 3.42 \\
\hline
\end{tabular}

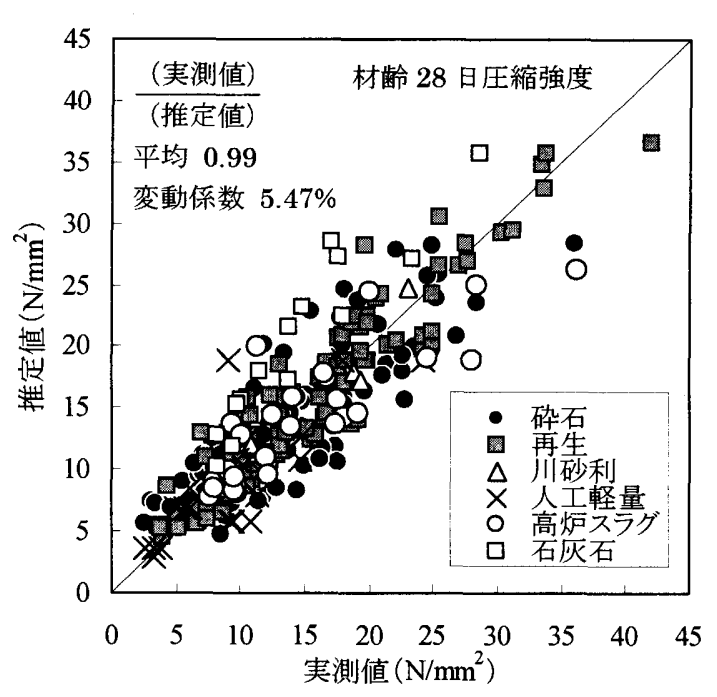

図 6 推定式による推定結果（骨材種類別）

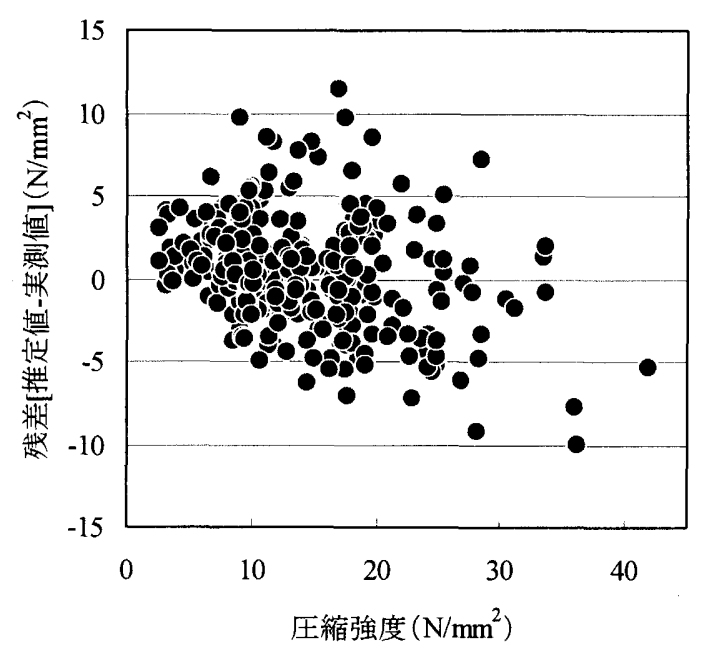

図 7 推定式による推定の傾向 


\section{5. まとめ}

本研究では, ポーラスコンクリートの骨材強度の違いが圧縮強度特 性に及ぼす影響について実験的検討を行うとともに, 圧縮強度の影響 要因を整理し, 圧縮強度推定式の構筑を行った。その結果, 以下の知 見を得た。

1）骨材強度がポーラスコンクリートの圧縮強度特性に及ぼす影響 は，骨材の絶乾密度を用いることでその影響俰数を精度良く求め ることができることが明らかとなった。

2） ポーラスコンクリートの標準養生材齢 28 日における供試体の圧 縮強度を推定する汎用的な式として，下記に示すような空隙率， 骨材絶乾密度および水セメント比を係数として組み込んだ式を 提案した。

$$
F c=12.6 k(0.48(C / W)-0.87) e^{0.61 D d-0.06 V a}
$$

ここに, Fc: 圧縮強度 $\left(\mathrm{N} / \mathrm{mm}^{2}\right)$

$k$ : セメント種類による影響倸数（普通, 早強ポルトラン ドセメントおよび高炉セメント B 種については， $k=1)$ $C / W:$ セメント水比

$D d:$ 骨材の絶乾密度 $\left(\mathrm{g} / \mathrm{cm}^{3}\right)$

$V a:$ 空隙率 $(\%)$

3）提案した圧縮強度推定式は, 高強度になると推定値を小さく算出 する傾向にあるが，全実測值を各推定値で除した值の平均值と， その平均值の変動係数を示すが, 平均值が 0.99, 変動係数が $5.47 \%$ と十分な精度を有している。

4）混和材が添加されたものに対して，シリカフュームを混入したも のは水セメント比を, 高炬スラグ微粉末を混入したものは水粉体 比を使用寸ることで推定が可能である。しかしながら，フライア ッシュなどのその他の混和材については, 現在有効な実験データ が存在せず，今後データを収集し，適用性について検討する必要 がある。

5）本推定式は標準養生された供試体の材㱓 28 日圧縮強度を推定す るものであり，現場封縅養生を行った供試体や実施工された構造 体の圧縮強度の推定には現時点では対応していない。この点につ いても今後，検討する必要がある。

6）高炉セメント C 種を用いた場合, 推定値を大きく見積もる傾向に あり，セメント強度の補正係数を掛ける必要があると考えられる。 今後, より多くのポーラスコンクリートの圧縮強度試験データを収 集し，推定式の精度および信頼性の向上を図るとともに，セメント種 類による影響係数を決定したい。

\section{【謝辞】}

本実験に使用した高炉徐冷スラグ骨材は（株）製鉄鉱業大分に提供 して頂いた。また，本実験を行うにあたり，大分大学工学部福祉環境 工学科建築コース清原千鶴助手, 遠矢義秋技官ならびに材料施工研究 室のみなさんにご協力頂いた。ここに記して謝意を表します。

\section{【参考文献】}

1）エココンクリート委員会: 委員会報告, コンクリート工学年次論文報告集, Vol.18, No.1, pp.19-28, 1996.6

2）日本コンクリート工学協会：ポーラスコンクリートの設計・施工法の確立 に関する研究委員会報告書，日本コンクリート工学協会，2003.5

3）大谷俊浩，村上聖，佐藤嘉昭，三井宜之，平居孝之：ポーラスコンクリー 卜の圧絔強度特性に及ぼす影響因子に関する研究一締固め程度および砕 石粒径が結合材の分布状態と圧縮強度特性に及ぼす影響一, 日本建勧学会 構造系論文集，No.585，pp.31-38，2004.11

4）大谷俊浩，村上聖，佐藤嗯昭，三井宜之，平居孝之：理想球形骨材を用い たポーラスコンクリートモデル供試体の圧縮強度理論に関する実験的研 究，日本建築学会構造系論文集，No.586，pp.7-13，2004.12

5）例えば 烟中重光，湯浅幸久，三島直生：再生骨材を用いたポーラスコン クリートの圧緶強度性状に関する研究, 日本建築学会構造系論文集, No.570, pp.31-36, 2003.8

6）村尾 健，湯浅幸久，三島直生，畑中重光：砕石並びに再生骨材を用いた ポーラスコンクリートの圧縮強度性状に関する実験的研究，日本コンクリ 一トエ学協会ポーラスコンクリートの設計・施工法と最近の適用例に関す るシンポジウム論文集, pp.71-76, 2002.5

7）石井武美: 粒子破砕の表示尺度のもつ物理的意義, 土僙工学会論文報告集, Vol.29, No.4, pp.155-164, 1989.12

8）伊藤雄輔，国枝稔，古川浩司，六郷恵哲：ポーラスコンクリート複合版の 力学挙動，コンクリート工学年次論女集，Vol.24, No.1, pp.1143-1148, 2002.6

9）音野环也，国枝稳，古川浩司，六郷恵哲：低品罂再生骨材を用いたポーラ スコンクリートのカ学特性, コンクリート工学年次論文集, Vol.24, No.1, pp.1149-1154, 2002.6

10）石黒拓，湯浅幸久，畑中重光：再生骨材を使用したポーラスコンクリート に及ぼす骨材品質の影響，コンクリート工学年次論文集，Vol.22，№.2, pp.1225-1230, 2000.6

11）黒田保，井上正一，吉野公，田中秀一：再生骨材の緑化コンクリートーの 適用性，コンクリート工学年次論文集，Vol.21，No.1，pp.181-186，1999.6

12）小椋伸司，国枝稳，栗原哲彦，六郷恵暂：ポーラスコンクリートの強度改 善，コンクリート工学年次論文集，Vol.19，No.1，pp.499-504，1997.6

13）柳橋邦生，米澤敏男，佐久間護，池尾陽作：緑化コンクリートに関する研 究および施工，コンクリート工学年次論文集，Vol.16，No.1，pp.871-876， 1994.6

14）張日紅, 中澤隆雄, 新西成男：ポーラスコンクリートの空隙率が圧縮強度 と态力ーひずみ関倸に及ぼす影響, セメント・コンクリート論文集, No.51, pp.864-869, 1997.12

15）金丸和光，川島満成，張日紅，金丸和夫：ポーラスコンクリートの圧縮強 度試験方法に関する一考察，セメント技術大会講演要旨, No. 54, pp.322-323, 2000.5

16）佐藤健司，長岡諴一，増岡臣一：コンクリート廃材を用いたポーラスコン クリートの開発，日本コンクリート工学協会ポーラスコンクリートの設 計・施工法と最近の適用例に関するシンポジウム論文集, pp.71-76, 2003.5

17）暒尾聡, 水口裕之, 片平博 : ポーラスコンクリートの乾湿繰り返し抵抗性 に関する研究，日本コンクリートエ学協会ポーラスコンクリートの設計 · 施工法と最近の適用例に関するシンポジウム論文集, pp.139-142, 2003.5

18）村尾健，湯浅幸久，三島值生，畑中重光：砕石並びに再生骨材を用いたポ ーラスコンクリートの圧縮強度性状に関する実験的研究，日本コンクリー ト工学協会ポーラスコンクリートの設計・施工法と最近の適用例に関する シンポジウム論文集, pp.71-76, 2002.5

19）例えば 依田彰彦，横室隆：微粉砕した高炬スラグを混和材として用いた モルタル・コンクリートの強度，セメント技術年報，42，pp.92-95, 1988.12

(2004年 9 月 9 日原稿受理，2004年12月27日採用決定） 